\title{
Neuroendocrine regulation of ovarian maturation in the Indian white prawn Penaeus indicus H. Milne Edwards
}

\author{
K. Sunilkumar Mohamed and A.D. Diwan' \\ Central Marine Fisheries Research Institute, P. B. 2704, Dr. Salim Ali Road, Cochin 682 031, Kerala \\ State, India \\ (Accepted 18 February 1991)
}

\begin{abstract}
Mohamed, K.S. and Diwan, A.D., 1991. Neuroendocrine Regulation of ovarian maturation in the Indian white prawn Penaeus indicus H. Milne Edwards. Aquaculture, 98: 381-393.

The control and regulation of ovarian maturation by neurosecretory elements in the eyestalk, brain and thoracic ganglia of Penaeus indicus have been examined. In the X-organ complex of the eyestalk, secretions from type $A$ and $B$ cells are apparently involved in inhibiting ovarian maturation, while in the brain and thoracic ganglia, secretions from type GN, A and B cells had a stimulatory effect on the ovary. The pyriform $C$ cells were not involved with ovarian maturation. Both unilateral and bilateral eyestalk ablation resulted in precocious maturation of the ovary. The histology of the remaining eyestalk in unilaterally ablated animals revealed that all the NSCs in the X-organs were in a suppressed state and the sinus gland was devoid of granular aggregations. Abnormal behaviour was noticed in bilaterally ablated prawns and strangely few animals moulted with developing ovaries. Due to the synchronous occurrence of moulting and reproductive activities the probability of both gonad and moult inhibiting hormones being the same is discussed. In addition the relationship between gonadal maturation and the moult cycle has also been studied.
\end{abstract}

\section{INTRODUCTION}

In recent times the aquaculture of penaeids has received an added impetus by the application of the eyestalk ablation technique to obtain precocious maturation and spawning. It was in 1970 that maturation was first observed in an ablated Penaeus duorarum (Caillouet, 1972), almost 30 years after Panouse (1943) first obtained precocious maturation in Leander serratus. Since 1970 , studies on induced maturation by eyestalk ablation in penaeids have multiplied (Alikunhi et al., 1975; Aquacop, 1975; Arnstein and Beard, 1975; Muthu and Laxminarayana, 1977; Lumare, 1979; Emmerson, 1980). Pres-

'To whom correspondence should be addressed. 
ently around 14 penaeid species have been matured and spawned in captivity using this technique (Primavera, 1984).

In spite of the almost routine use of the technique of eyestalk ablation in penaeid prawn hatcheries, very little is known about the morphological and physiological changes that occur in the neuroendocrine system operating under these circumstances. In Decapoda, only few attempts have been made to correlate changes in the gonad with those in the neuroendocrine organs (Matsumoto, 1958; Perryman, 1969; Babu et al., 1980; Kulkarni and Nagabhushanam, 1980; Rao et al., 1981; Joshi, 1989). Such studies have added significance, especially in penaeids, as hatcheries are becoming increasingly dependent on endocrine manipulations to achieve their production targets.

The neurosecretory cell types and their cyclic secretory activity in Penaeus indicus have been reported earlier by Mohamed (1989). In the present investigation, attempts have been made to correlate the structural changes in the neurosecretory cells to different phases of ovarian maturation. Eyestalk ablation experiments were performed to study the NSCs concerned with the regulation and control of ovarian development. In addition, the relationship between gonadal maturity and the moult cycle has also been examined.

\section{MATERIALS AND METHODS}

Live adult females of $P$. indicus ( $140 \mathrm{~mm}$ and above) used in the study were collected from the sea off Cochin using short-duration otter trawls. The prawns were then segregated according to a five point maturity scale ranging from stage I (immature) to stage IV (mature) and stage V (spent) (King, 1948 ).

The various neuroendocrine centres, namely, optic, supraoesophageal, suboesophageal and thoracic ganglia, as well as the ovaries of the prawns in each maturity stage were dissected out and fixed in Bouin's fluid for 24-48 h and then processed for histological studies. Approximately $6-8 \mu \mathrm{m}$ thick sections were cut and stained with Gomori's paraldehyde fuchsin (Kurup, 1972) for visualization of neurosecretory cells (NSCs) in the ganglia. Routine staining was, however, carried out with hematoxylin and eosin. Disulphide and sulphydryl groups of protein and glycogen are reported to be the principal components of the NSC in P. indicus (Mohamed, 1989). Hence histochemical tests with appropriate controls were carried out to detect the variation in these components in ganglia from all maturity stages according to Pearse (1968).

The NSCs in the optic, supraoesophageal, suboesophageal and thoracic ganglia of animals in different maturity stages were classified into three phases based on their secretory activity as described by Mohamed (1989). The phases were quiescent (Q), vacuolar (V) and secretory (S). The number of cells in each phase in all the ganglia was recorded for each maturity stage. Such cell 
counts were made from three animals at same maturation stage and the average percentage was calculated.

\section{Eyestalk ablation experiments}

To study the role of eyestalk neurosecretory hormones on ovarian maturation, experiments were conducted at the Marine Prawn Hatchery Laboratory (MPHL) of CMFRI at Narakkal.

Female prawns above $140-\mathrm{mm}$ TL obtained from the grow out ponds in the hatchery complex were used in the study after acclimatization to laboratory conditions for $48 \mathrm{~h}$. Animals were maintained in 3-feet diameter collapsible plastic pools (Plasticrafts Corp., Bombay) with a capacity of 0.25 tons. Stored and settled seawater (salinity, 28 to $36 \mathrm{ppt}$; temperature, 27 to $30^{\circ} \mathrm{C} ; \mathrm{pH}, 8.0$ to 8.2 ) was used and aeration was provided from an air-grid. Prawns were fed ad libitum with fresh or frozen clam meat. The uneaten food and faecal matter were siphoned out and $50 \%$ of the water was replaced daily.

Forty immature females of $P$. indicus in intermoult $(\mathrm{C})$ and early premoult $\left(D_{0}\right)$ stages were selected and divided into four experimental groups (I, II, III and IV) of ten animals each. In group I, prawns were maintained without any treatment for a period of 10 days and served as the intact control. In group II, animals were subjected to unilateral ablation of the right or left eyestalk. Both eyestalk of the prawns were removed in group III (bilateral eyestalk ablation ). Eyestalk ablation was performed with the help of an electrocautery apparatus. Experimental animals were examined daily for signs of gonadal development. The development of the ovary could be clearly seen through the transparent dorsal cuticle and the formation of the triangular ovary in the first abdominal somite was taken as an indication of full maturity (stage IV). The number of days taken for attaining stage IV by each prawn was recorded as the latency period. Animals were sacrificed on reaching stage IV or after 10 days, whichever was earlier. The final moult stage was recorded and the gonads of each prawn were weighed for the determination of gonado-somatic index (GSI). Further the eyestalk, brain, suboesophageal and thoracic ganglia and the gonads were preserved in Bouin's fluid for histology.

In group IV unilateral eyestalk surgery was performed for all 10 prawns and simultaneously these prawns were administered an aqueous extract of fresh eyestalk. Eyestalk extract (from immature females) in the ratio of 2 eyestalks $/ 0.2 \mathrm{ml}$ was prepared by macerating fresh eyestalks in cold crustacean saline $(3.4 \% \mathrm{NaCl}, \mathrm{pH} 7.4)$. The extracts were then centrifuged at $3000 \mathrm{rpm}$ for $10 \mathrm{~min}$ and the supernatant was used for the injections. Each of the animals was injected once with $0.2 \mathrm{ml}$ of the extract into the first abdominal somite using a hypodermic syringe. After an experimental period of 10 days, all the animals were sacrificed and their GSI and ova diameter were determined. Results of the experiments were compared using Student's $t$-test. 


\section{RESULTS}

\section{Relationship between NSC phases and maturity stages}

The histological examination of the optic, supraoesophageal, suboesophageal and thoracic ganglia of wild females in different maturation stages revealed the significant changes taking place in the NSCs of these ganglia in relation to ovarian maturation. The mean percentage occurrence of NSCs in different phases of their secretory cycle (quiescent, vacuolar and secretory phases) in relation to ovarian development is given in Table 1.

In the eyestalk X-organ complex of immature females, more than $75 \%$ of the NSCs were in the physiologically active $\mathrm{V}$ and $\mathrm{S}$ phases (Fig. 1). In animals with fully mature gonads, the ratio of inactive to active cells was almost $1: 1$. In the spent stage, the cell percentage did not differ significantly from that of the mature stages. In marked contrast to the pattern observed in the eyestalk, in the supraoesophageal, suboesophageal and thoracic ganglia, the trend was the reverse. In the supraoesophageal ganglia of immature females a majority of the cells were in the $Q$ phase and very few were in the $S$ phase (Fig. 2). In the supraoesophageal of fully mature females, physiologically active NSCs together numbered more than $80 \%$ (Fig. 3 ). There was however, little change in this status in spent females. In the suboesophageal and thoracic ganglia, the changes in NSC phases were similar to that observed in the brain, although it was to a considerably lesser extent in the suboesophageal ganglion.

\section{Histochemical responses of NSCS}

Remarkable variations in the histochemical response of NSCs were observed in relation to the progress in ovarian maturity. The results of the histochemical tests on the optic, supraoesophageal and thoracic ganglia of immature, mature and spent females are presented in Table 2.

TABLE 1

Mean percentage occurrence of NSCs in different phases of the secretory cycle in relation to the female maturity stages in different neuroendocrine centres of wild $P$. indicus

\begin{tabular}{|c|c|c|c|c|c|c|c|c|c|c|c|c|}
\hline \multirow[t]{2}{*}{ Maturity stages } & \multicolumn{3}{|c|}{ Eyestalk (X-organs) } & \multicolumn{3}{|c|}{ Supraoesophageal } & \multicolumn{3}{|c|}{ Suboesophageal } & \multicolumn{3}{|c|}{ Thoracic } \\
\hline & Q.Ph. & V.Ph. & S.Ph. & Q.Ph. & V.Ph. & S.Ph. & Q.Ph. & V.Ph. & S.Ph. & Q.Ph. & V.Ph. & S.Ph. \\
\hline I-Immature & 23.4 & 35.3 & 41.3 & 64.2 & 28.0 & 7.0 & 59.1 & 30.6 & 10.3 & 77.7 & 12.8 & 9.5 \\
\hline II-Early maturing & 43.9 & 31.0 & 25.1 & 60.6 & 23.7 & 16.7 & 51.7 & 26.8 & 21.5 & 42.0 & 25.0 & 33.0 \\
\hline III-Late maturing & 42.2 & 33.8 & 24.0 & 34.3 & 33.5 & 32.2 & 40.0 & 37.7 & 22.3 & 34.7 & 26.8 & 38.5 \\
\hline IV-Mature & 47.3 & 29.6 & 23.1 & 19.8 & 32.2 & 48.0 & 25.5 & 31.6 & 42.9 & 13.9 & 30.7 & 55.4 \\
\hline V-Spent & 51.5 & 24.7 & 23.8 & 19.0 & 33.9 & 47.1 & 23.9 & 32.0 & 44.1 & 14.2 & 30.2 & 55.6 \\
\hline
\end{tabular}

Q.Ph. = quiescent phase; V.Ph. = vacuolar phase; S.Ph. = secretory phase.

Average of three observations. 


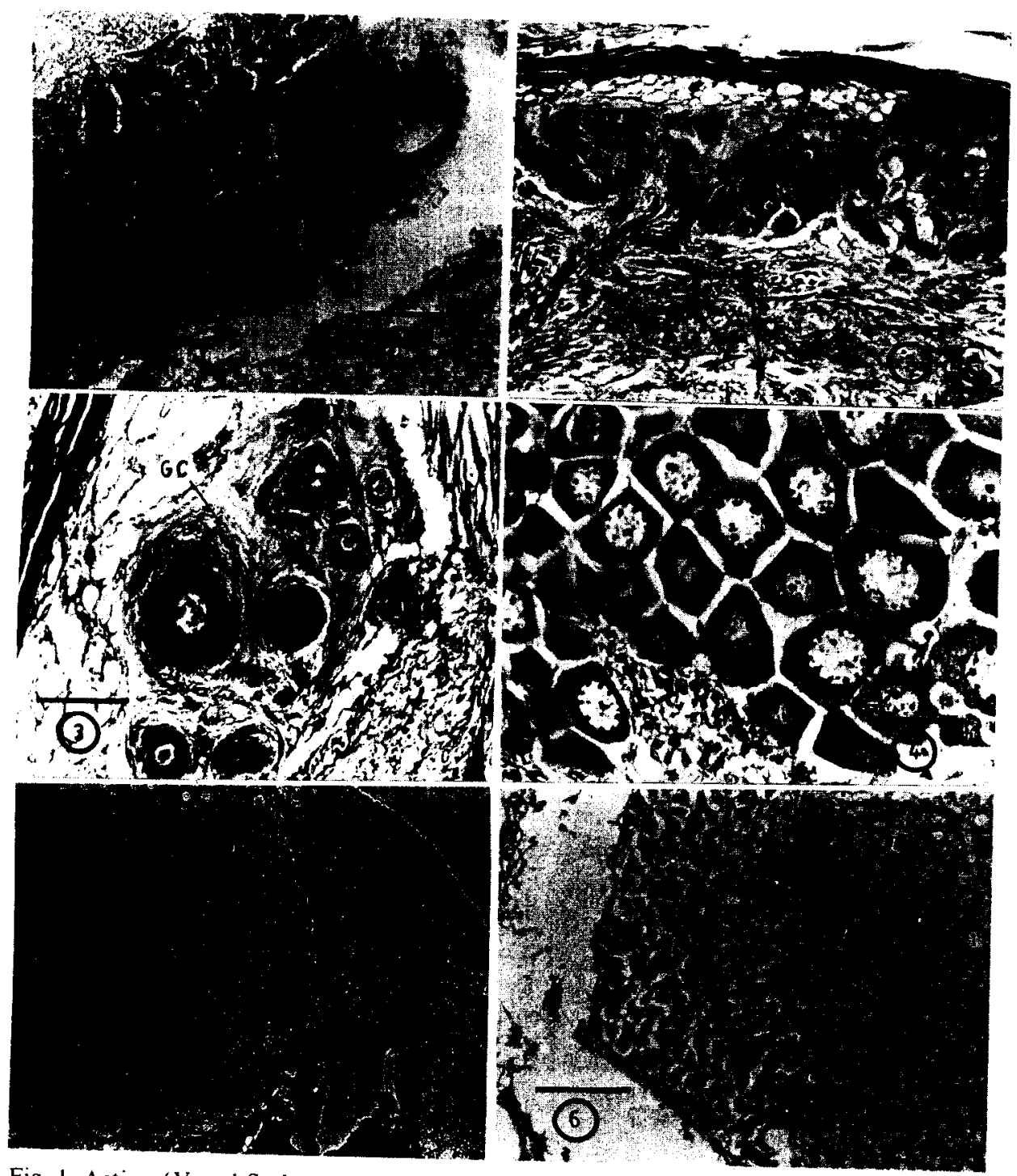

Fig. 1. Active (V and S phase) neurosecretory cells ( $A, B$ and $C$ cells) in the MTGXO of an immature female. Bar equals $50 \mu \mathrm{m}$.

Fig. 2. Large number of quiescent (Q) phase NSCs in the supraoesophageal ganglion of an immature female. Bar equals $100 \mu \mathrm{m}$.

Fig. 3. Active NSCs in the supraoesophageal ganglion of a fully mature female. Note the A cell with hypertrophied glial cells $(\mathrm{GC})$ and the intensely granular cytoplasm. Bar equals $50 \mu \mathrm{m}$. Fig. 4. Previtellogenic oocytes in the ovary of an untreated (group I) immature female. Hematoxylin and eosin. Bar equals $50 \mu \mathrm{m}$.

Fig. 5. Ovary of a group II unilateral eyestalk ablated female having oocytes in fully mature state with peripheral cortical bodies (CB). N, nucleus. Hematoxylin and eosin. Bar equals $100 \mu \mathrm{m}$. Fig. 6. MEGXO of the remaining eyestalk in a unilaterally ablated mature female. All cells have equals $150 \mu \mathrm{m}$. 
TABLE 2

\begin{tabular}{|c|c|c|c|c|c|c|c|c|c|c|c|c|c|}
\hline \multirow[t]{2}{*}{ Ganglion } & \multirow{2}{*}{ Histochemical tests } & \multicolumn{3}{|l|}{ A cells } & \multicolumn{3}{|c|}{ B cells } & \multicolumn{3}{|c|}{$\mathrm{C}$ cells } & \multicolumn{3}{|c|}{ Sinus gland } \\
\hline & & $\mathrm{IM}$ & M & $\mathrm{S}$ & IM & M & $\mathrm{S}$ & IM & $\mathrm{M}$ & $\mathbf{S}$ & IM & $\mathbf{M}$ & $\mathrm{S}$ \\
\hline \multirow[t]{4}{*}{ Optic } & $\begin{array}{l}\text { 1. Ferric-ferricyanide } \\
\text { test-SH group } \\
\text { Control-Mercaptide }\end{array}$ & & + & ++ & + & \pm & \pm & + & \pm & + & + & \pm & \pm \\
\hline & $\begin{array}{l}\text { Control-Mercaptide } \\
\text { 2. PFAB test--S-S group }\end{array}$ & \pm & $\overline{+}$ & $\bar{t}$ & $\overline{t+}$ & $\bar{t}$ & $\overline{+}$ & $\overline{+}$ & \pm & $\overline{-}$ & $\overline{t+}+$ & & - \\
\hline & $\begin{array}{l}\text { 2. PFAB test--S-S group } \\
\text { Control-Alcian blue alone }\end{array}$ & $\begin{array}{l}+ \\
-\end{array}$ & \pm & \pm & $\begin{array}{l}++ \\
-\end{array}$ & \pm & \pm & - & $\begin{array}{l}I \\
-\end{array}$ & - & $\begin{array}{l}+++ \\
\pm\end{array}$ & $\begin{array}{l}+ \\
-\end{array}$ & $\begin{array}{l}++ \\
\pm\end{array}$ \\
\hline & $\begin{array}{l}\text { Control-Alcian blue alone } \\
\text { 3. PAS test-glycogen } \\
\text { Control-Diastase }\end{array}$ & $\overline{t+}+$ & + & ++ & + & + & + & + & + & + & $\begin{array}{l}++ \\
\pm\end{array}$ & + & 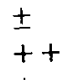 \\
\hline & 1-Diastase & + & - & - & + & & & \pm & & - & & \pm & \pm \\
\hline \multirow{4}{*}{ Supraoesophageal } & $\begin{array}{l}\text { Control--Mercaptide } \\
\text { 2. PFAB test }\end{array}$ & \pm & ++ & $\dot{+}+$ & $\begin{array}{l} \pm \\
+\end{array}$ & + & ++ & \pm & $\overline{+}+$ & \pm & \pm & $\begin{array}{l}++ \\
-\end{array}$ & $+t$ \\
\hline & Control-Alcian blue alone & - & - & \pm & \pm & $\overline{t+}$ & \pm & $\bar{t}$ & $\overline{t+}$ & $\begin{array}{l}+ \\
-\end{array}$ & \pm & $\begin{array}{l}- \\
+ \\
-\end{array}$ & \pm \\
\hline & $\begin{array}{l}\text { 3. PAS test } \\
\text { Control-Diastase }\end{array}$ & $\begin{array}{l}+ \\
\pm\end{array}$ & $\begin{array}{l}+t \\
+\end{array}$ & $\begin{array}{l}+ \\
\pm\end{array}$ & $\begin{array}{l}++ \\
+\end{array}$ & \pm & \pm & $\begin{array}{l}+ \\
\pm\end{array}$ & $\begin{array}{l}+ \\
\pm\end{array}$ & \pm & + & & $\begin{array}{l}+ \\
-\end{array}$ \\
\hline & Control-Diastase & \pm & & & & & \pm & & & \pm & \pm & $\begin{array}{l}+ \\
\pm\end{array}$ & \pm \\
\hline \multirow{5}{*}{ Thoracic } & $\begin{array}{l}\text { 1. Ferric-ferricyanide test } \\
\text { Control-Mercaptide }\end{array}$ & \pm & ++ & $\begin{array}{l}+ \\
-\end{array}$ & $\begin{array}{l}+ \\
-\end{array}$ & + & - & $\begin{array}{l}+ \\
\pm\end{array}$ & ++ & + & \pm & $\begin{array}{l} \pm \\
++\end{array}$ & \pm \\
\hline & $\begin{array}{l}\text { Control-Mercaptide } \\
\text { 2. PFAB test }\end{array}$ & $\overline{t+}$ & ++ & + & + & ++ & ++ & $\begin{array}{l} \pm \\
+\end{array}$ & - & - & - & $\begin{array}{l}++ \\
-\end{array}$ & + \\
\hline & $\begin{array}{l}\text { 2. PFAB test } \\
\text { Control-Alcian blue alone }\end{array}$ & \pm & \pm & - & - & $\overline{-}$ & & - & $\begin{array}{l}+-1 \\
-\end{array}$ & \pm & + & $\overline{t+}$ & - \\
\hline & 3. PAS test & + & ++ & \pm & \pm & $\begin{array}{c}+ \\
-\end{array}$ & $\begin{array}{l}+ \\
-\end{array}$ & \pm & $\bar{t}$ & - & - & $\begin{array}{l}++ \\
-\end{array}$ & \pm \\
\hline & Control-Diastase & - & \pm & - & - & & & - & $\begin{array}{l}+ \\
\pm\end{array}$ & ++ & \pm & $\overline{+}$ & - \\
\hline
\end{tabular}

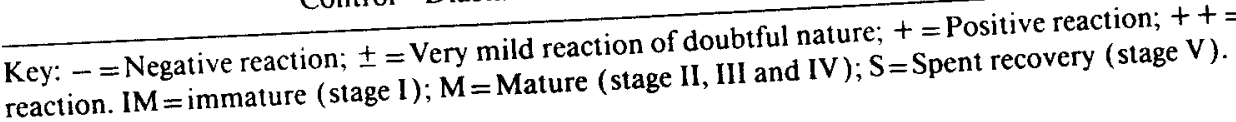


In the optic ganglia, the NSCs displayed maximum positivity for sulphurcontaining amino acids and glycogen in the immature stage and minimum positively in the mature and spent stages. A and B cells were the most active cell types in the $\mathrm{X}$-organs by virtue of the magnitude of variation in the reactions. Maximum activity of the sinus gland was also observed in the immature stage. In the supraoesophageal and thoracic ganglia however, GN, A and $B$ cells were the most active in relation to gonadal maturation.

\section{Eyestalk ablation and ovarian maturation}

Results of the experiments carried out to find the role of the X-organ sinus gland complex on ovarian maturation are summarized in Table 3.

In the experimental group I, untreated females, no ovarian development took place. During the 10 days of experiment, all the animals which were initially in intermoult $(C)$ and/or early premoult $\left(D_{0}\right)$ stages advanced to premoult and late premoult without moulting. Histologically the ovary showed the characteristics of an immature gonad with previtellogenic oocytes (Fig. $4)$. All group II animals exhibited significant increase $(P<0.01)$ in their GSI and oocyte diameter as compared to group I animals. In this group, apart from an initial loss of equilibrium, no behavioural changes were observed after ablation although food intake was substantially increased. The latency period for maturation ranged from 4 to 9 days. Full maturity with oocytes in the vitellogenic phase was attained by $90 \%$ ot the experimental animals (Fig. 5 ). There was no significant change in the moult stage during the period.

The histology of the remaining eyestalk (the that was not ablated) revealed that all the NSCs in the MTGXO and MEGXO were in a suppressed state. The cytoplasm of these cells was uniformly agranular and homogenous, as is characteristic of Q phase NSCs (Fig. 6). The sinus gland of these animals lacked granular inclusions and stained lightly with aldehyde fuchsin (Fig. 7) when compared to the sinus gland of an immature female (Fig. 8). Further the majority of NSCs in the supraoesophageal and thoracic ganglia were in the $\mathrm{V}$ and $\mathrm{S}$ phases (Fig. 9).

TABLE 3

Details of eyestalk ablation experiments in relation to gonadal maturity in $P$. indicus

\begin{tabular}{lllllll}
\hline $\begin{array}{l}\text { Expt. } \\
\text { group }\end{array}$ & $\begin{array}{l}\text { Mean total } \\
\text { length }(\mathrm{mm})\end{array}$ & $\begin{array}{l}\text { Mean latency } \\
\text { period } \\
\text { (days) }\end{array}$ & $\begin{array}{l}\text { Moult stage } \\
\text { Initial }\end{array}$ & $\begin{array}{l}\text { Final } \\
\text { GSI }\end{array}$ & $\begin{array}{l}\text { Ova diameter } \\
\text { range }(\mu \mathrm{m})\end{array}$ \\
\hline I & 142.5 & 10 & $\mathrm{C} / \mathrm{D}_{0}$ & $\mathrm{D}_{0} \mathrm{D}_{2-3}$ & 0.488 & $20-100$ \\
II & 146.7 & 5.9 & $\mathrm{C} / \mathrm{D}_{0}$ & $\mathrm{C} / \mathrm{D}_{0}$ & 5.699 & $164-347$ \\
III & 142.3 & 3.7 & $\mathrm{C} / \mathrm{D}_{0}$ & $\mathrm{~B} / \mathrm{C} / \mathrm{D}_{2-3^{*}}$ & 4.035 & $60-346$ \\
IV & 145.4 & 10 & $\mathrm{C} / \mathrm{D}_{0}$ & $\mathrm{C} / \mathrm{D}_{0} / \mathrm{D}_{1 *}$ & 0.904 & $20-150$ \\
\hline
\end{tabular}

*Three prawns moulted once with developing ovaries and two died during the effort to moult. 


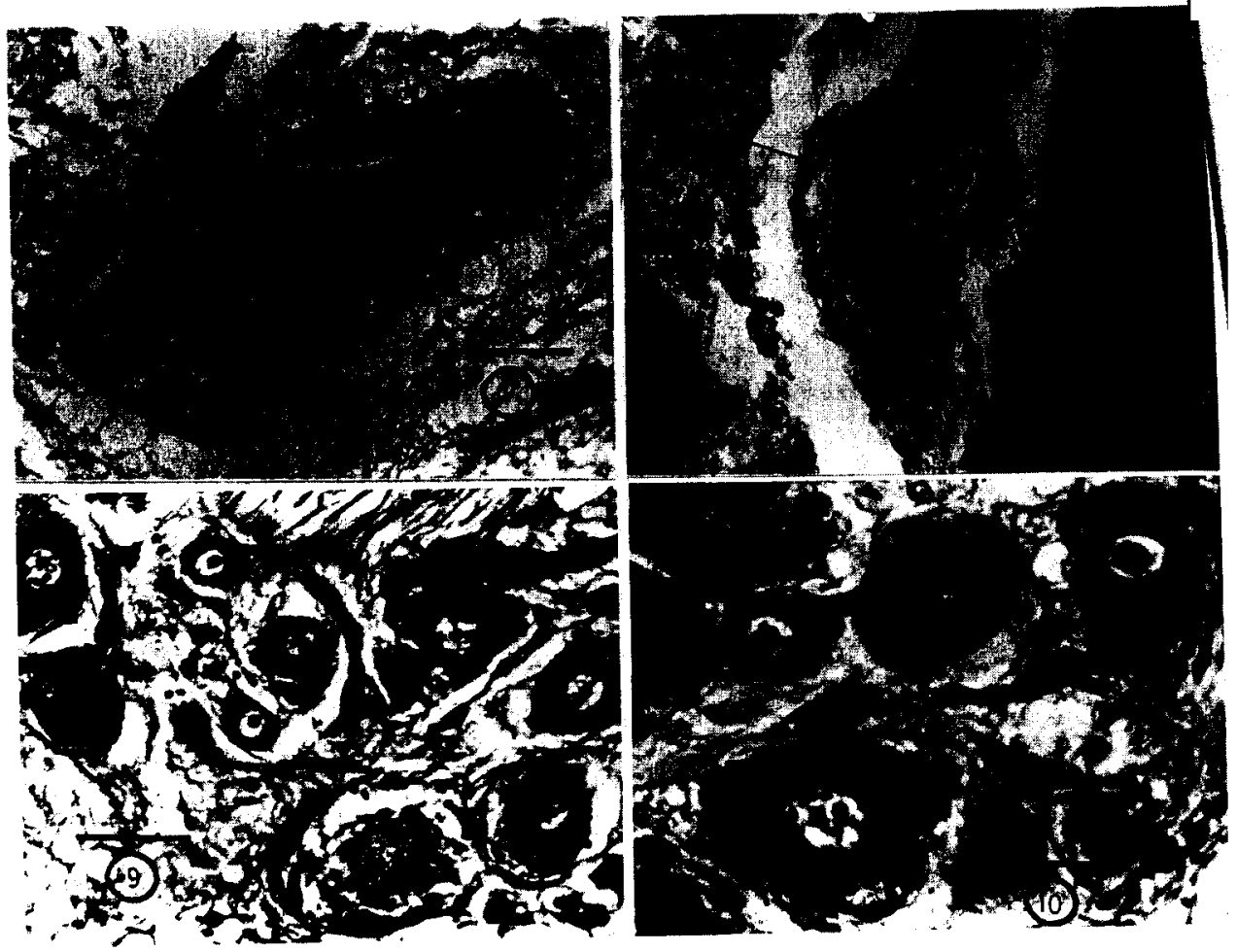

Fig. 7. The sinus gland of the same animal is lightly stained and devoid of granular inclusions IS. internal blood sinus; AX, axonal ending. Bar equals $100 \mu \mathrm{m}$.

Fig. 8. The sinus gland of an immature female with swollen axonal endings (AX) and secretory granules. IS, internal blood sinus. Bar equals $100 \mu \mathrm{m}$.

Fig. 9. Very active $B$ cells ( $S$ phase) in the thoracic ganglion of a unilaterally ablated female in advanced stage of maturity. Bar equals $50 \mu \mathrm{m}$.

Fig. 10. Hyperactive B and C cells in the supraoesophageal ganglion of a bilaterally ablated mature female (group III). Bar equals $25 \mu \mathrm{m}$.

The bilateral eyestalk ablated animals (group III) showed significant behavioural abnormalities. Immediately after the extirpation of both the eye. stalks, prawns were seen to swim at the surface in circles with abnormal speed Almost within a few hours, these prawns became dark red in colour due to the dispersion of chromatophores. Feeding was observed to be voracious. In thi: group $50 \%$ of the individuals attained full maturity. The average latency pe riod was 3.7 days, which is considerable shorter than that observed in groul Il ( 5.9 days). Interestingly three prawns with developing ovaries moulted an two others with developing ovaries died during the moulting process. Moult 


\begin{tabular}{|c|c|c|c|c|}
\hline \multirow[t]{2}{*}{ Moult-stages } & & \multicolumn{3}{|c|}{$\%$ occurrence of ripe (stage IV) females } \\
\hline & & Wild $(n=61)$ & $\begin{array}{l}\text { Unilateral } \\
\text { eye ablation } \\
(n=10)\end{array}$ & $\begin{array}{l}\text { Bilateral } \\
\text { eye ablation } \\
(n=8)\end{array}$ \\
\hline $\begin{array}{l}\text { Postmoult } \\
\text { Intermoult } \\
\text { Premoult }\end{array}$ & $\begin{array}{c}A \\
B \\
C \\
D_{0} \\
D_{1} \\
D_{1} \\
D_{1} \\
D_{2-3} \\
\end{array}$ & $\begin{array}{c}0 \\
0 \\
18.03 \\
81.9 \\
0 \\
0 \\
0 \\
0\end{array}$ & $\begin{array}{l}0 \\
0 \\
10.0 \\
90.0 \\
0 \\
0 \\
0 \\
0\end{array}$ & $\begin{array}{c}0 \\
12.5 \\
25.0 \\
50.0 \\
0 \\
0 \\
0 \\
12.5\end{array}$ \\
\hline
\end{tabular}

ing itself was abnormal as it was observed during daylight hours. The NSCs (Fig. 10). Both V and S phase NSCS the animals were in a hyperactive state ganglia.

in all the NSC groups in the with an aqueous extract of the eyestalk ablated females were administered 0.904 . This value was marginally higher, the mean GSI was estimated to be nificantly lower $(P<0.01)$ than that of groups of the control but was sig10-day latency period, the NSCs in all the gangs II and III animals. After the ilar to that existing in an immature female.

\section{Relationship between gonadal maturation and moult cycle} stages is given in Table 4. In samples obtaine IV) females in different moult ing were in interipe females were in early premoult (Dild population more lateral eyestalk able $(C)$ stage. A similar pattern $\left(D_{0}\right)$ stage. The remainerable variation in the females. In the bilateral eyestalk also observed in uniwere in $D_{0}$ and $C$ the above pattern was observed. Totllated group considpremoult $\left(D_{2}\right.$ stages. However, $12.5 \%$ of the mature $75 \%$ of the animals $12.5 \%$ were in which is the terminal stage prior to emales were in late uniquely, mature postmoult (B) stage. More importan. The remaining ing and developed ands in B and $C$ stages had mouportantly and perhaps

\section{DISCUSSION}

In $P$. indicus, NSCs in $V$ and $S$ phases dominated in the MTGXO and
MEGXO in the eyestalk of immature females. Subsequently in the ripe stage 
Q phase NSCs dominated. The sinus gland was swollen with disulphide-rich secretory granules in the immature stage and it was devoid of granular inclusions in the mature stage. Similar cytological differences in the activity of the X-organ NSCs were correlated with the seasonal activity of the ovary in the shrimp, Pandalus gracilis (Aoto and Nishida, 1956), and in the freshwater crab, Potamon dehaani (Hanaoka and Otsu, 1957). Kulkarni and Nagabhushaman (1980) have shown in Parapenaeopsis hardwickii that the activity of the ovary (gonad) inhibiting hormone (GIH) was the highest in the eyestalks of females with inactive and spawned ovaries, whereas it was negligible in those at full vitellogenesis. However, in the present study, spent animals also had a large percentage of inactive NSCs. This is probably because of the small time-interval between stage IV and V and it could also explain the findings by Muthu(1983) that once $P$. indicus reaches reproductive maturity and spawns, it is able to undergo the process of rematuration within a short period of time.

The histological and histochemical results obtained in the present study showed that $\mathrm{A}$ and $\mathrm{B}$ cells in the X-organ complex of $P$. indicus were maximally active during the immature stage and therefore these cells may be responsible for the elaboration of a factor which inhibits the maturation of the gonad. Added evidence to this statement comes from the histological evaluation of the remaining eyestalk in prawns induced to mature by unilateral eyestalk ablation. All the NSCs in the MTGXO and MEGXO, particularly B cells, were in a suppressed state and the sinus gland was devoid of any secretory material.

Both unilateral and bilateral ablation of the eyestalk led to precocious maturation of the ovary and the same was inhibited by the injection of an eyestalk extract confirming that gonad inhibitory principles are present in the eyestalk. Also, in destalked male $P$. japonicus, an aqueous extract of the eyestalk of $P$. vanname $i$ was found to inhibit the precocious development of the spermduct (Chim et al., 1983). Among female penaeids, eyestalk ablation has so far been synonymous with unilateral eyestalk ablation. Arnstein and Beard (1975) and Santiago (1977) observed that arientalis and $P$. monodon respecwas sufficient to induce maticus, Muthu and Laxminarayana (1977) reported that unilateral eyestalk ablation was sufficient to induce precocious maturation as was observed during the present investigation. Bilateral ablation was observed to result in abnormal behaviour and incomplete maturation of the ovary. Identical results were obtained by Caillouet (1972), Alikunhi et al. (1975) and Muthu and Laxminarayana (1977).

In $P$. indicus, on occasions, bilateral ablation also led to moulting with maturing ovaries, an event which Adiyodi and Adiyodi (1970)reported as rare in crabs. Aquacop (1975) noted that they had never seen a penaeid moulting with developed ovaries except for a bilaterally ablated $P$. aztecus. Accelerated 

moulting rate has been observed in $P$. merguiensis after bilateral ablation by
Alikunhi et al., ( 1975 ), although they did not observe gonadal maturation
side by side. The instance of synchronous occurence of
ductive activition ductive activities due to bilateral eyestalk occurrence of moulting and reprothe hormones involved in inhibiting mouling suggest the possibility that GIH) are the same. Such an eventuality ting and reproduction (MIH and Adiyodi (1970) when they argued the possibility discussed by Adiyodi and Howe chemically related molecules produced from the of both GIH and MIH being rate peptides whenbush (1986) suggested that both NSCs in the X-organs. ablation is also he reviewed the progress made in thiH and GIH are sepa1985). However, Vijay to shorten the moult cycle in in isolation. Eyestalk that though bilat Vijayan (1988) reported in immature femaceans (Chang, failed to do bilateral ablation shortened the moult cycle, unales of $P$. indicus lateral ablation present study seems to indicate that the emplateral ablation during unilateral inhibitory hormones removed) was toward mis during biward maturation. ablation (half of inhibitory hormones remard moulting and state of the anim. Therefore, at least in penaeids, apart fromoved) it was to-

The NSCs of the circulating inhibitory hormone lom the physiological tent the suboesope supraoesophageal and thoracic ganglia and also significant. mature $P$ indichageal ganglion were maximally active in late maturer excorrelated the stas. In the crayfish Procambarus simulans, Perryman cretory material in cell type III of the cerebral ganglion. Such a high of neurose-
activity during ovarian maturation harying amount in the thoracic ganglan maturation has also been observed a high secretory Potamon kootion of Macrobrachium lankesteri (Rad in specific NSCs praoesophagealense (Joshi, 1989). The histochemical observation 1981) and and $B$ cells present thoracic ganglia indicate that the secretions of the sueffect on the ovary. ing factor comes from thional evidence for the elaboration of this stimutory in these ganglia after the observation of heightened neurosecretory stimulatMenippe rumphii bilaterateral and bilateral ablation. Similarly activity cretory material from the eyestalk ablation resulted in the relarly in the crab al, 1980). Further the NSCs of the brain and thoracine release of neuroseganglion more pror they observed that the secretory activic ganglion (Babu et ment of thoracic NSCs in than the cerebral ganglion, suggesting the invoric and thoracic NSCS in reproduction. In $P$. indicus however, the involve-

Crustaceans regulate go to be equally involved.

balance between the two processes (Quatic growth to achieve an optimum organisation of these two processes Charniaux-Cush, 1986), and based on the into moulting type 2, wherein gonadal and somatic growth ) fitted shrimps ously. However, in prawns sampled from the wild growth occur simultane- 
that maturation almost always occurred in the early premoult stage. Not surprisingly, this is the moult stage in which the animal stays the longest (Vijayan, 1988). This indicates that penaeid prawns actually fit somewhere in between type 1 (where reproduction takes place during the long intermoult period) and type 2. Results obtained by Emmerson (1980) and Crocos and Kerr (1983) were also similar when they correlated events in the reproductive and moult cycle in $P$. indicus and $P$. merguiensis respectively. However, in the present study, this pattern was observed to be grossly disrupted in the bilaterally ablated group, although unilateral ablation seemingly did not affect it.

\section{ACKNOWLEDGEMENTS}

We are grateful to Dr. P.S.B.R. James, Director, Central Marine Fisheries Research Institute, Cochin and Dr. E.G. Silas, former Director, for providing facilities and encouragement. We are also thankful to the scientists and staff of the Marine Prawn Hatchery Laboratory, Narakkal, Cochin for help with the experimental work. The grant of a Senior Research Fellowship to one of the authors (KSM) by the Indian Council of Agricultural Research is also acknowledged.

\section{REFERENCES}

Adiyodi, K.G. and Adiyodi, R.G., 1970. Endocrine control of reproduction in decapod Crustacea. Biol. Rev., 45: 121-165.

Alikunhi, K.H., Poernomo, A., Adisukresno, S., Budiono, M. and Busman, S., 1975. Preliminary observations on induction of maturity and spawning in Penaeus merguiensis de Man and Penaeus monodon Fabricius by eyestalk extirpation. bull. Shrimp Cult. Res. Cent., 1:111.

Aoto, T. and Nishida, H., 1956. Effect of removal of the eyestalks on the growth and maturation of the oocytes in a hermaphroditic prawn, Pandalus kessleri. J. Fac. Sci. Hokkaido Univ. Ser. 6, 12: 412-424.

Aquacop, 1975. Maturation and spawning in captivity of penaeid shrimps. Penaeus merguiensis de Man Penceus japonicus Bate, Penaeus aztecus Ines, Metapenaeus ensis de Haan and Penaeus semisulacatus de Haan. Proc. World Maricult. Soc., 6: 123-132.

Arnstein, D.R. and Beard, T.W., 1975. Induced maturation of the prawn Penaeus orientalis inouye in the laboratory by means of eyestalk removal. Aquaculture, 5: 411-412.

Babu, D.E., Shyamasundari, K. and Rao, K.H., 1980. Correlative changes in the neurosecretion growth after bilateral ablation of eyestalk in the crab, Menippe rumphii. Indian J. Exp. Biol., 18: 265-268.

Caillouet, A.C., Jr, 1972. Ovarian maturation induced by eyestalk ablation in pink shrimp, Pen.

Chang, E., 1985. Hormonal control of moulting in decapod Crustacea. Am. Zool., 25: 179-185.

Cotton, H., 1985. Vitellogenesis and its control in malacostracan Crustacea. Am. Zool., 25: 197-206.

Chim, L., Kleinholz, L.H., Payen, G.G. and Laubier-Bonchon, A., 1983. Inhibiting effect of an eyestalk extract from male prawn Penaeus vannamei Boone on the precocious development 
of the genital apparatus of the eyestalkless male $P$. japonicus Bate. C.R. Acad. Sci. Paris, 296:
185-190.

Crocos, P.J. and Kerr, J.D., 1983. Maturation and spawning of the banana prawn Penaeus mer-
guiensis de Man (Crustacea Pexal gulensis de Man (Crustacea Penaeidae) in the Gulf of Carpenteria, Australia. J. Exp. Mar.
Biol. Ecol., 69: 37-59. $121-131$

. Trog. Ser. 2 of the crab Potamon dehaani. J. Fac. Sci. Hokkaido ovarian inhibiting hormone in the cyestalk Joshi, P.C., 1989. Neurosecretion of brain and thoraco Univ. Ser. 6, 13: 379-383.

in the female crab Potamon koolooense (Rathbun) ganglion and its relation to reproduction 98: 41-49.

King

setiferus (L). Biol. Bull., 94: 244-262.

Kulkarni, G.K.

eyestalk of marine penaeid prawn (Parapenaeopsis ovary inhibiting hormone from the mental cycle. Aquaculture, 19(1): 13-19.

Kurup, N.G., 1972. Staining 19(1): 13-19.

Hydrobiol., 40:87-110.

Lumare, $F$, $1979.87-110$ 18: 203-214.

Matsumoto, K., 1958 . Univ., 4: $103-176$

studies on the neurosecretion in crabs. Biol. J. Okayama aeus indicus $\mathrm{H}$. Milne Edwards. $\mathrm{Ph}$. $\mathrm{D}$ thesis, Cochin India, $252 \mathrm{pp}$.

Muthu, M.S., 1983. Broodstock developmen and Seed Production and Hatchery Management management. In: Proc. Natl. Symp. Shrimp Muthu, M.S. and Laxminarayana, A., 1977. InduPEDA, Cochin, India, pp. 97-116. aeid prawns. Indian J. Fish., 24: 172-180.

Panouse, J.B., 1943. Influence de l'ablation du chez la crevette Leander serratus. C.R. A du pédoncule oculaire sur la croissance de l'ovaire

Pearse, A.G.E., 1968. Histochemistry, Theoretical Paris, 217: 553-555. $758 \mathrm{pp}$.

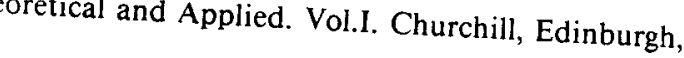
and in the ovarian cycle. Trans. Am simulans - light induced change in the neurosecretory cells

Primavera, J.H., 1984. Maturation Am. Microsc. Soc., 88: 514-524. ternational Conference on the Culture of Pention in closed thelycum penaeids. In: First InPhilippines, pp. 47-64. Quackenbush, L.S., 1986.

2271-2282.
Rao, N.K., Shakuntala, K. and Renstacean endocrinology, a review. Can. J. Fish. Aquat. Sci., 43: ganglion in relation to reproduction in female Macrobrachium neurosecretion of the thoracic

Indian Acad. Sci. (Anim. Sci.), 90: 503-511.
Santiago, A.C., Jr, 1977. Successfucrobrachium lankesteri (de Man). Proc. eyestalk ablation. Aquaculture, 11: 185-196.
Vijayan, K.K., 1988. Studies on the Penaeus monodon Fabricius after

dicus. Ph. D thesis, Cochin University of Scion moulting in the penaeid prawn, Penaeus in- 